解明のところで，インターロイキン 6 (IL-6) の関与を示唆されましたが, 我々も IL-6 産生腫 瘍の患者の臨床症状が更年期障害と同じ症状であ ることを経験して居ります。どうも先生ありがと うございました。あとでまた，よろしくお願いい たします。それでは，最後に漢方医学の立場から 寺澤先生にお願いしたいと思います。寺澤先生は 漢方の方では有名で，皆さんご存じない方いらっ しゃらないと思いますので，簡単にご紹介いたし ます。

炤和 45 年の 3 月に, 千葉大学医学部をご卒業さ れまして, 千葉大学医学部神経内科で勉強されて おりましたが，その後富山医科薬科大学の和漢診 療部講師になられ，以後助教授から教授になられ ました。平成11年の11月からは富山医科薬科大学 の医学部長をなさっておられます。漢方医療専門 の教授が医科薬科大学の医学部の教授会の運営を なさるというのは日本で初めてと考えます。

寺澤先生は, もちろん漢方の素養は非常に豊富 でいらっしゃるのですけれども，国立大学の医学 部の中に漢方の診療部を作られて, 周りは西洋医 学の医者ばかりだと思うのですが，そういう中で 立場をどんどん作って来られました。先程申しま したように日本の医療体系というのは，行政上は 西洋医学なわけですが，そこに漢方をどのように 進めていくかということを，身をもって体験して 居られます。先程後山先生は漢方を受ける立場で いらっしゃったのですが，こちらからは西洋医学 の中にどのように入っていってそこに定着するか という問題を中心に抱負まで含めて先生よろしく お願いいたします。

\section{3. 漢方医学の立場から}

寺澤 捷年

富山医科薬科大学医学部和漢診療学講座

寺澤 大分皆さんお疲れだと思いますが，しば らくおつきあいをお願いしたいと思います。大澤 先生，本当にごていねいなご紹介をありがとうご ざいました。

先程，厚生省の方からもなかなか厳しい，どこ へ行っても厳しいです。大体，国の予算が84兆円 で動いてますけれども，赤字国債を31兆円くらい 出しています。赤字国債が累積していて，それを 返すのに20兆ぐらい使っているわけですから，84 兆円といっても20引きますから，使えるのは六十 何兆円になってしまうわけです。いろいろ厳しい 状況なのです。今のまま，つまりこの20世紀とい うものが歩んできたような方法論の延長線上で考 えるから厳しいのであって，これはひとつ発想を 変えてみたらずいぶんとゆったりしたものになる と思うのです。

その中でやはり，21世紀の医療の中に，漢方と いうものがしっかりと定着していくということが, 今，破綻状態にある医療保険制度を救う大きな一 つの切り口になると確信しております。その確信 の実例などは，最初に裏过先生等が臨床の現場で 患者さんがみるみる漢方薬によって驚くほどよく なっていくということを言いました。私も週に何 回か外来をやってますから，そういうことを確信 しております。

確信はしておりますが，今，大澤先生がおっ しゃったように，ほとんどの日本の大学はいわゆ る西洋医学というもののアカデミズムがある。そ れから，医療保険制度での審査の基準とか判断, そういうものもいわゆる西洋医学的な発想でくる。 それから，私ども大学に身を置きますと，文部省 の科学研究費の採択，あるいは厚生行政全般，こ れがすべて西洋医学的な発想といいますか，その 基盤には西洋自然科学というものがあるわけです 
が，その発想でくるわけです。こういうところと どういうふうに折り合いをつけていくかというこ とを，近々のうちに達成できるかできないかとい うことが，漢方が本当の意味で医療の中に根を下 ろすか下ろさないかの分かれ目になってくるとい うことになります。

今, 後山先生が括しくださったようなものは, 西洋医学の立場からといいますけれども，相当に 大きなエビデンスを与えてくれていますから，婦 人科領域では温経湯というのはこういうものなの かということで，相当根を下ろしますから，温経 湯というものの使い勝手がよくなるし，その評価 も高まってくるということです。こういうことの 積み重ねに尽きると思います。

雑談になりますが, 私の大学で17診療科, 私ど もを入れて 18 診療科ですが，非常に漢方に積極的 に取り組んでくれている教室が産婦人科です。そ れから皮膚科, 諸橋先生には今朝, 座長をやって いただいていました。諸橋先生の皮膚科，それか ら早坂先生の眼科, この 3 つの診療科は非常に積 極的です。それからそのほかに当然, 消化器外科, 泌尿器科, 整形外科の一部というところです。

私は20年間も富山医科薬科大学におりますと, 今, 新しい斉藤教授に代わる前までは, 産婦人科 からの紹介患者とか, コリレーションは一回もな かったです。今の新しい若手の教授は，「これか らの産婦人科領域には絶対に漢方を使わなくては いけない。私はこの富山医科薬科大学に赴任して くるのを楽しみにしていました」という男ですか ら，今はがっちりと手を組んで，こちらからも人 を出して，漢方外来を立ち上げて若い人を育てる ということもやっているわけです。ここで言える ことは，どうも今言ったような領域は非常に漢方 の手助けがある部分では必要だと感じている領域 です。

最も遠いのが循環器内科などです。内科の先生 は一般に遠いわけです。というのは，自分の診断 治療学にもの寸ごい自信があるわけです。ここに 漢方なんていう非科学的と思われるようなものは 一切入り込む余地はない, と思っていますね。外 科の先生は, 比較的単純で「治ればいい」という
感じですから, 外科の先生や整形外科の先生は, 結果オーライなら何でもいいと。スイングが曲 がっていようが曲がっていまいが200ヤード飛べ ばいいという感じです。そういう非常にプラクテ イカルな, ペイシェント・オリエンティッドな医 療をするのです。いわゆる, 純粋な内科の先生と いうと，少しかたくななところがある。

そういう中では，大澤先生などは大変例外中の 例外の教授だったのではないかと思います。現職 時代から漢方に目を向けておられる。しかし，そ れは先生が内分泌学というのをやられたから，そ のモジュレーターである漢方薬などにも注目され てくれたのではないかなと思っています。つまり， 非常に今のこの2000年の時点で, 治療手段がほぼ 確立していると信じられている領域にはなかなか

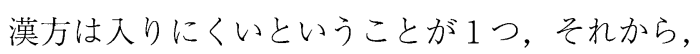
とはいえ，本当にそのリーダー，教授というよう な席の人が代わるだけで変わるということは，つ まり指導者の価值観というものがどうおかれるか によって若い人が全然違ってきてしまうというこ とで，教育や研究をリードする人の見識というも のも非常に大事だということを日常の中で痛感し ているというのが現状です。

ところで，そういうことになりますと現実問題 として，最初に申し上げましたように，いわゆる 西洋医学の論理で当面は評価され, そういう評洒 に耐えなければ根を下ろしていけない。昨日も大 澤先生と話していたのです。要するに，ただの浮 き草であってはだめだ。先生はいいことを言うの です。やっぱり地面にちゃんと根を下ろさなけれ ばいけない。しかし，その根を下ろす場所という のは，最初の大澤先生のスライドにありましたよ うに，一応，そういう西洋医学的な，いわゆるサ イエンティフィックといわれている思考過程とい うのが土壤としてあるわけですから，そこにうま く入り达んで，実はしかしそれ以上のものである ことを示していかなければいけないということで す。

後山先生のご講演は大変すばらしかったのです が，一つだけ反対することがある。漢方はきわめ て自然科学的な体系だというのだけれども，そう 
ではないのです。自然科学をも取り込んだもっと 大きな体系なのです。自然科学というものは「も の」を普遍的に, 客観的に数值化する, 計量化で きるものを計量化するという学問です。しかし， 人間は何のために生きるのか，何に幸せを感じる のか, こういうものは計数化できないのです。で すから，自然科学はその場所に立ち入ることがで きない。つまり, 人間の存在というのは当然のこ とながら, 自然科学というものを超えた存在であ る。その一部のエビデンス, 再現性のある, 計数 化できる，計量化できる，こういったものについ てのみ科学というものは取り扱える, ということ をはっきりと認識しなければいけないのです。そ うすると, そういう思考過程, 土壤がある中で, どうやってその幼い哲学を持った人たちを教育し ていくか，そこの中に根を下ろしていくかという ことについては，十分，東洋医学会に集う私たち が考えていかなければいけないだろうと思います。

今日はどの講演会場も午前中から，私，今日ま じめに会場を回りましたし，また特別講演等も聞 かせていただきましたが，厚生省のお話を除けば, 「こうしたら漢方薬はよくなる」という話, 松田 邦夫先生の「和田東郭の話」は医療哲学に通じる ものがあったように思っております。

漢方医学が次の世紀の医療に対して提言できる ことが2つあると思います。それは「養生」とい う言葉の思想を再確認していくという大きな提言 をもっていることと，もう一つは「自然治癒力」 ということです。自然治癒力というのは計測でき ません。人間トータルが外界, あるいは中の内乱 因子に対してディフェンスしたり，修復したりし ていく機構ですから, 自然治癒力という力は計量 化できないわけですが，自然治癒力と称するもの を賦活化したり，正常化できる，この 2 つのこと だと思います。

そこで今週の日曜日に1日かけまして1論文 (原稿用紙 5 枚) を書きまして，これは読売新聞 社の文化欄に投稿しました。向こうの求めに応じ て投稿したわけです。7月13日に読売新聞社の文 化欄に出ますが，2つのメッセージ，それは「養 生」と「自然治穏力」, この 2 つのことをしっか
りと再認識しないと日本の医療はとうてい立ちゆ かないという論調であります。

先日, うちの医学部 4 年生の講義がありました。 黒板に「養生」という字を書きました。「これを 何と読むか? 読み方を書いて，このことの内容を 知っていると思う人は $\bigcirc$ ，ちょっとわかるかなと いう人は $\triangle$ ，全然わからないという人はメをつけ てくれ」と，出席カードでアンケートをとったの です。そうしましたら，これを「養生（ようじょ う)」と，あるいは「ようせい」というのもいま した。朝に, 北里大学の東医研の小曽戸先生にお 伺いしましたら，日本では通常「ょうじょう」と 読みますが，仏教的な影響を受けた読み方だ。中 国学をやっている人はこれを「ようせい」と読む のだそうです。そこで学生たちの答えで「よじょ う」も「ようせい」も○にしまして，それでよく わかっていると思うという人の○の数を数えます

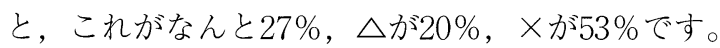
つまり，これは「ようせい」なり「ようじょう」 とは大抵読めますが，中身はほとんど知らないと いうことです。

この言葉がそもそも医書（書物）に現れるのは いつごろかと思って，このことについて十分研究 しているわけではありませんが,たまたま『荘子』 という本を解説した諸橋轍次先生の『荘子物語』 という本が講談社学術文庫で出ておりますが，そ れをひもといておりましたら，この「養生（よう せい，あるいは，ようじょう)」の一章があるわ けです。

「人間の存在はそもそも自然の法則の中にある ことを自覚し，自身の健康に留意することが重要 である。その第 1 の要点は, 食事の摂取量をはじ めとして何事もひかえめにすることである。そし て第 2 には，社会生活を営むうえで，我欲を捨て， 執着の心を捨てることだということが書いてあ ります。またこの次のところには，「生きよう生

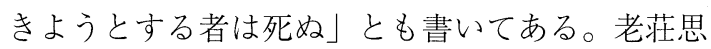
想の神髄が書かれております。

このことはとても大事です。というのは，この ごろ「ライフスタイル病」ということを言われま す。生活習慣病と訳されております。例えば糖尿 
病であるとか, 動脈硬化性の疾患（心筋梗塞だと か脳卒中)，さまざまなものが生活習慣の誤りに よって起こるのだということが言われます。しか しどうでしょうか。そうすると生活習慣といって 大体気がつくのが食べ物あるいは，睡眠時間のこ となどということを思います。大体, 栄養・連動 ・休養, この 3 つらいのことが養生の, 生活習 慣を乱す基本的な要素と言います。

しかし, 東洋の思想では, その根幹に社会生活 を営むうえで，私の欲を捨てて執着の心を捨てる ことだというところまで言っているわけです。こ のことの意味は非常に大きいと思います。つまり， 食生活が乱れ，睡眠時間が乱れる。どうして乱れ るのか。それは今よりもいい車を買ってみたい, 大きい家に住みたい，おいしいものを食べてみた い，金が欲しい。結局のところ，自分の欲である とか，あるいは社会的な地位を高めたいとかです。 その欲が自分の生活を乱してしまう大きな要素で ある。ここのところは「生活習慣病」ということ が解説されてある本のどれにも書いてないです。

しかし，すでに2300年以上前に，東洋の哲学は すでのそのことをはっきりと明記していることを 私たちは誇りにも思わなければいけませんし, 逆 に東洋医学を担う者は，「この漢方薬が効いた」 とか「今, 西洋医学よりは漢方医学の方がいいの だ」とか，治療手段としての漢方治療というもの の優越性を論じるだけでなくて，もっと根本的に， 自分自身の生き方をも含娖元を見直していく ということが必要なときを迎えているように思い ます。

と申しますのは，例えば糖尿病をはじめとする 生活習慣病, 糖尿病には単なる高血糖状態から, 網膜症から失明に至る, あるいは腎機能障害から 腎透析にいく，腎不全になって腎の透析に入る， 神経炎が起こってくる。特に腎透析，あるいは網 膜の障害による失明などは本人にとっても非常に 深刻ですけれども，国の医療経済にとっても非常 に深刻です。今，もうまもなく 10 人に 1 人が糖尿 病に罹患するという時代を迎えると推測されてい ます。確かにそうです。

このごろの中学生のトレンドはポテトチップス
を食べながらコカコーラのペットボトルの1リッ トルびんを飲むというものです。渋谷の駅前に 行っても，富山の駅前でもみんな中学生がそうし ているのです。そして，満足な食事もしない。食 ベたいときはいつでもカップラーメンが食べられ る。こんなことをしていて若々しく元気な社会な んてできるわけがない。そういうことに対して， 少なくとも医学界がもっともっと大きく積極的に 発言をしていくべきなのに，日本医師会は保険薬 価の改定とかそういうことだけに汲々していて， 本当のところ国民がどうしたら幸せになれるかに ついては十分な配慮と投資もしてない，というの が私の実感です。

この「養生」の心に立ち返るとすれば，糖尿病 の患者さんも，初期に見つかったら食事療法をし ますけれども, 食事療法あるいは降血糖薬とか経 口糖尿病薬とかインスリン治療を成功させるため には, 結局, その人の「生きる」ということの価 值観からある部分では変えていかなければいけな い。変えるというか, 少なくとも理解しあうとい うところにもっていかないと成功しない。

そんなことを考えておりましたら，やはり大澤 先生から昨日, 衝撃的な話を聞いたのです。アメ リカの糖尿病センター, ジョンスリンの糖尿病セ ンターの所長さんは, 今, ジェイコブソンという 精神科の先生なのだそうです。なぜ精神科の先生 が，世界有数の糖尿病センターの所長さんなので しょうか。つまり，単にインスリンを打って血糖 值を下げるとかそういうことではなくて，その人 の価值観ともせめぎあってそういう治療をうまく まっとうして，こちらのいい治療法に向こうが納 得して入ってくる格好にしていかなければいけな いので，それは単に何単位のインスリンを打った らこうなるといっているような内科医のレベルを 超えてしまっていると, そういうことを座長の大 澤先生から教えていただきました。私の考えはあ まり間違っていなかったな,でもそんなことは 2300年以上前に東洋ですでに提唱している「養 生」の根本思想であるということを感じたわけで あります。その点が第 1 点です。

第 2 点目は, これから明らかにしていかなけれ 


\section{漢方医学のシステム制御論（Ｉ）}

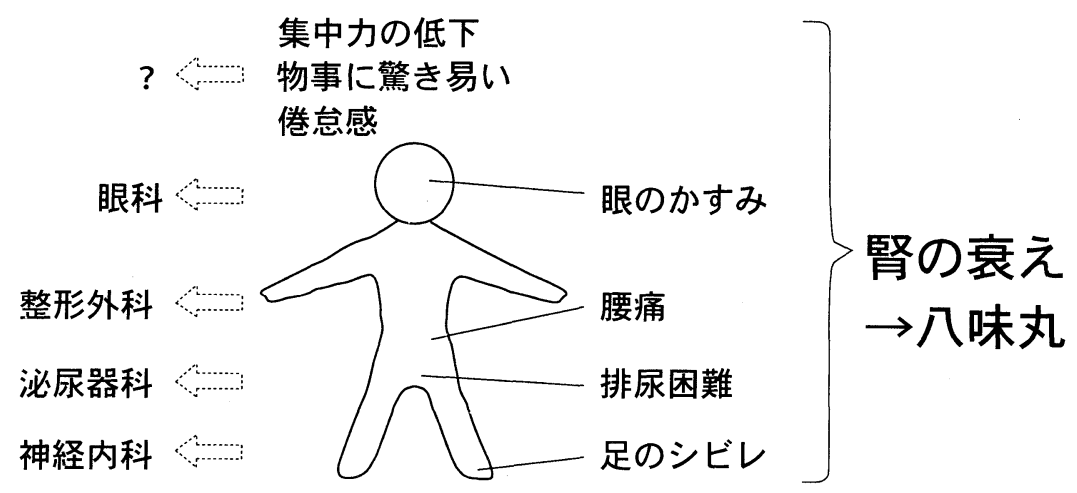

図 1

\section{漢方医学のシステム制御論（II）}

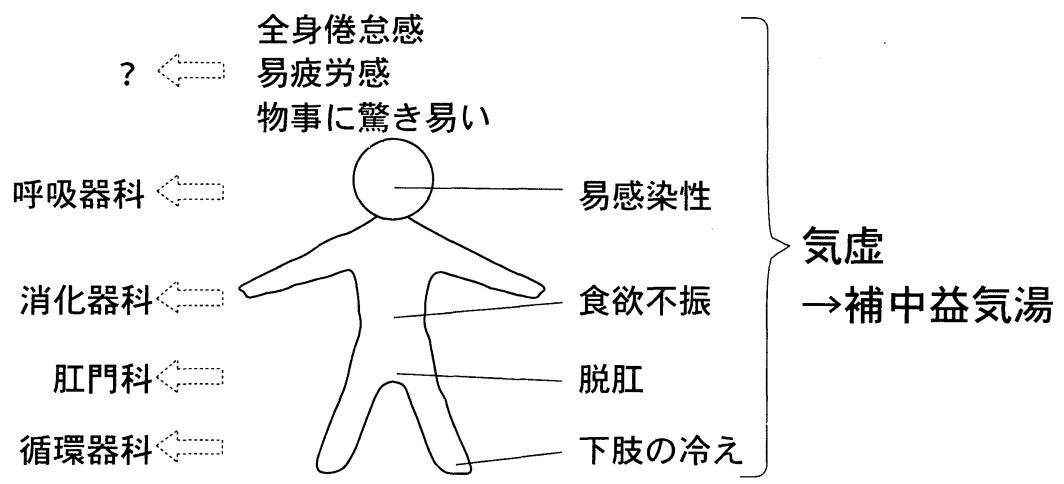

図 2

ばならないのは，どうしても西洋医学というのは 臓器別になっていきます。肝臓が悪ければ肝不全 になったら肝藏の移植をしようとか, 腎臓の移植 をする，あるいは透析をする。臓器別ですが，漢 方がもっているのは，こういうシステム制御論で す。目がかすんでみたり, 腰が痛んだり, 排尿障 害・困難がきたり，足がしびれがくるというもの は，腎というシステムの衰えであると認識する。 そして，それを一つの八味丸なり何なりという一 つの方剤で制御できるということです。このこと の意味というのは非常に大きいです。

もちろん個々の分化した医学の発展というのは これから一人でに進んでいくところですが，ばら
ばらな医療を本当の意味で統合していく。この知 恵というものは漢方医学がもっている，ここのと ころにしっかりとした科学的なエビデンスを与え ていく。科学的なという意味は, みんなが納得す るような方法で八味丸なり何なりのシステム制御 が正しいのだということを客観的に証明していく ということが，私たちに今課せられている使命た と思います（図１）。

裏辻先生の例にもありましたように，補中益気， 湯，いろいろな症状が出ます。しかし，このさま ざまな症状を気虚として，例えば補中益気湯とい うものでこれを制御していける。しかも，先程の 八味地黄丸にしても補中益気湯にしても，あるい 
表 1

\section{1世紀の医療に漢方医学が十分に 役割を果たすための課題}

\section{I . 治療体系の普遍化 \\ II. 漢方方剤の有効性の客観的評価法 \\ III. マンパワーの育成}

は十全大補湯や人参養栄湯，いわゆる補剤と言わ れるようなものは，失調状態に陥った，あるいは 低下してしまった自然治癒力を回復していくこと は，皆さんすでにご承知のとおりです。何とかこ のことを薬効の客観性を求めていくことが, 当面, 非常に大切なことだろうと思っています（図 2)。

時間がだいぶきました。結局, 求められるのは, 治療体系を普遍化し，それから，今言ったような システム論をも含めた漢方方剤の有効性を客観的 に評価していこう。当然のことながら，そういっ たものに根ざしたマンパワーを育成するというの が，21世紀において本当に地に足をつけた漢方医 学の発展が望める 3 つの要素であろうと思います

(表 1 )。

この漢方方剂の生薬化学，あるいは生薬薬理学, 複合成分の薬理はまだまだ手つかずですがだいぶ 手が続いてきました。血清薬理，これは田代先生 が提唱していますがこういったものも必要に なってくるでしょう。しかし，この部分は相当に， 今，進みつつあります。

患者の病態生理, 病態生理学。こういったもの, 先程後山先生は, 冷え性の患者さんの病態生理を 明らかにしてくれました。ああいった漢方の古典 が人間のシステムを全体に見ているものだとする と，その一部は確実に科学的に解明できます。で すから，そういったものを動員してやっていこう。 それから、トータルアウトカムを客観的に評価し ていく。ともかく患者さんはブラックボックス, 漢方方剤はある意味ではブラックボックスです。 しかし，ブラックボックスにブラックボックスを ある法則で与えてアウトカムがよければそれでい
いわけですから，これを客観的にとらえていくと いうのが当面の課題だと思います（図３）。

今，二重盲検法が進んでおりまして，とりあえ ずこれでやると一番いいわけです。西洋医学的な 発想で薬の評価をしている人たち，端的に言えば 厚生省の審査官の人たちが最も納得できますし， 中央薬事審議会の委員の先生方もわかるというわ けです。ですから，これにしょうがないから乗せ ていかなければいけないというのが一つの時代で あります。

そこで今, 再評価指定 8 品目のうち小柴胡湯, 大黄甘草湯, 小青竜湯, こういうものが今進んで, 終わりました。今，あと残りの品目はまだデー夕 は公開されておりませんが, 相当にいい結果が出 ています。こういうような方法がもしできるとす ればいいのですが，非常に時間と費用がかかりま す。それから漢方の特色を場合によっては損なっ てしまうという，非常に妥協したものであること になってしまいます。というのは，例えば慢性肝 炎ひとつとってみても，慢性肝炎は別に小柴胡湯 だけの処方ではありませんから，もし慢性 C 型 肝炎において小柴胡湯が効くということを検定し ようとすれば，漢方的にみて小柴胡湯の「証」の グループをあらかじめ取り出すという作業が必要 です。

しかし，このことがなかなか難しいのです。と いうのは，漢方的に小柴胡湯の「証」というのを 見抜ける人がこの世の中に，特に大学病院の中に はあまり多くありません。こういう二重盲検比較 試験ができるのは，およそ大学病院を中心とした 地域基幹病院までなのです。そうすると，「鶏が 先か，卵が先か」ではありませんが，この切り出 しになかなか成功しにくい。そうすると，大变不 利な状態で二重盲検比較試験をしなければいけな いというのが現状です。

そこで今考えられているのは，ある漢方薬の効 果を客観的に示してみたいと思うときには，その 薬をまず投与してみる。例えば私が，この患者さ んは小柴胡湯ではないかと, そうしたら効かない 人と効く人が出る。先程の裏辻先生の例ではあり ませんが，飲んだら大体 1 週間目ぐらいで患者さ 


\section{治療体系の普遍化}

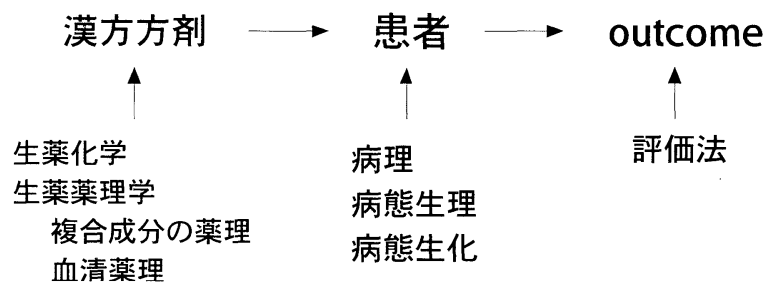

図 3

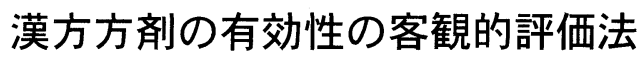

二重盲検臨床比較試験

ノンレスポンダ限定デザイン

（試験薬による漸増法）
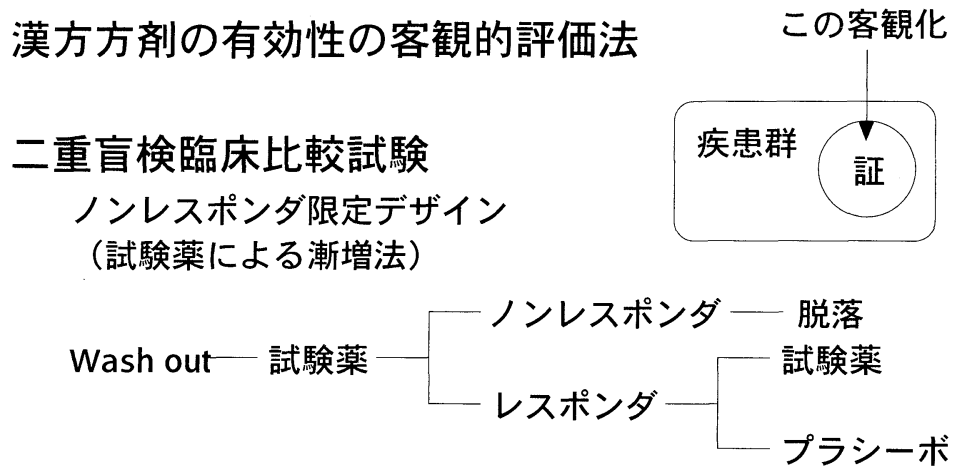

\section{$\mathrm{N}$-of-one}

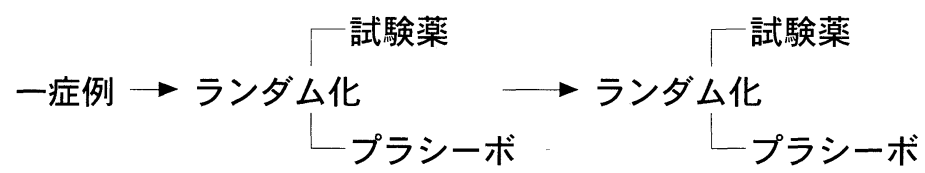

図 4

んは「この薬，いいかもしれません」と言うので す。当たった感じがする。そうしたら，その人を 選んで無作為化して本当の薬とプラセボとの間の 盲検試験をやっていく。この間は数週間で済みま す。 $2 \sim 3$ 週間，あるいは疾患にもよりますが， 早いものだったら 2 週間くらい，長くても 4 週間 くらいで勝負がつきます。こうすると，この漢方 薬の「証」というものに合った人だけが試せます から，そこで決着がつくことがあるかもしれない ということが言えます。

それから,いろいろ勉強してみますと, N-of-one

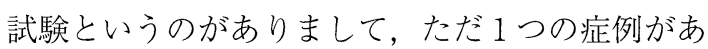
ります，例えばアレルギー性鼻炎の人が来たとす る。この患者さんをランダム化しまして試験薬を 投与するか，プラセボを投与してみる。もうしば
らくしたら，それをまたランダム化して試験薬か プラセボをまたかけてみるというかたちをします と，きわめて少ない症例数である薬のこの病態に 対する効果がわかるということも, 研究方法論と してあることがわかりました。今度こういうもの を動員しながらエビデンスを出して，根を生やす ためには西洋医学の隙間にバシッと入っていかな ければいけません。そういうエビデンス・ベース トの漢方医学というものを一歩一歩築いていくの も，これから漢方が本当の意味で定着していく一 つの切り口かなと思っております（図４）。

大澤 寺澤先生，どうもすばらしい括をあり がとうございました。

お伺いしておりまして，漢方というのは科学, あるいは医学だけではないというお話でした。私 
自身，医学というのは西洋医学でも科学だけでは ないと考えてきました。生化学を例にとりますと， 理学部の生化学の教室の先生方と, それと私たち のように医者で, 特に臨床をやりながら生化学, 遺伝子操作をやっているものにとって，テーマが 全く同じことがあります。例えばサイトカインな んかは, 先程後山先生の話で出てきました。その ときに, 理学部の学者のなさることは真理の追究 ですが, 医学部で生化学をやる立場では, 真理の 追究だけでなく，その成果が患者にどう戻せるか ということがなければ医学ではないという立場を とってきましたので，先生がとにかく東洋医学は 医学，科学だけではなくて哲学も含んだ，要する に人を中心とした学問，医療であるというお話を 伺い非常に感銘しました。

特にさっきのアラン・ジェイコブソンは，私自 身が先程スライドを使ったのがジェイコブソンの スライドなのですが，患者中心の医療が大切で, 疾患医療だけではだめになってきたと主張してい るわけです。どうもありがとうございました。

\section{〔総合討論〕}

大澤 それでは 3 人の先生方, 壇上に上がって いただけますでしょうか。実はこのスタートが15 分遅れましたので，あと20分ほど時間があるので すけれども，懇親会に間に合わないと困ると思う ので，少し時間をはしょらないといけないかもし れません。 3 人の先生方, 今日のシンポジウムで ご発言ありがとうございました。進行の勝手で申 し訳ありませんが，私自身が一番知りたいこと， あるいは皆さん方も知りたいということをまずデ イスカッションして, 時間があればフロアの先生 方, あるいは演者からのデイスカッションを碩 いしたいと思います。

最初にも述べましたが，漢方の医療が明治の時 期に非常に厳しい状況になりまして，私の先生の 大塚敬節先生などは非常に大変な時期を切り開い て来られたわけです。それが突然漢方が普及しは じめました。いろいろな理由で普及したわけです。 ちょうど浮き草が池に最初浮かんでいたのが，ど んどん増えて一面緑色でもう全面覆われて，漢方 が非常に普及し流行しているという状況になった と見えていたところへ，例えば保険の診療から外 すという問題が出ました。そういう石が厚生省か らポンと投げられますと大騷ぎになるというわけ です。

それで，どこかに根を張っていない浮き草では 困るということを考えておりました。漢方がこれ だけ普及し，それから研究も今日の括を伺って も非常に進んできました。しかしながら，20世紀 は今年で終わるわけですが，そのちょうど架け橋 の年にあたって，そこまでは来たと思うのですけ れども，これからちゃんと日本の医療に根付いて もらわないと困る。特に診療の第一線に抢られる 裏辻先生のようなプライマリーケアの先生方が, 患者さんが来られたときに，西洋医学であろうが 東洋医学であろうが患者中心に，患者にとって最 も優れた医療を提供できなければ最高の医療では ないと思われます。そのためには，日本の医療の 中に漢方が根付いていないと困る，定着していな いと困るというわけです。浮き草では困る。それ 
を定着させるにはどうやったらいいかというのが 今日の主題であるわけです。

そういう意味で，まず先生方に伺いたいと思う のですが，漢方の有用性というのはいろいろなか たちから皆さん方が言っておられると思います。 裏辻先生が第一線の診療をなさっておられて, 西 洋医学の経験もおありなのですが，漢方が第一線 の診療においてどのような位置づけにあるでしょ うか。例えば，漢方がどうしても必要な領域とい うのは確実にあると考えてよろしいでしょうか。

裏辻 漢方は奥が深くて，まだまだうがったこ とは申せませんが，生体の恒常性が何らかの原因 で乱れた病態を正常化するのは漢方治療の特長で あると考えています。それで，漢方は機能的疾患 によく効くといわれるのだろうと思うのですが， 私は現代医学的治療に反応の乏しいものには広く 適応すると考えておりますので，絶対必要な領域 であると思います。

大澤 後山先生，いかがでしょうか。先生の立 場から, 大学病院で産婦人科の臨床をやってい らっしゃいまして，西洋医学を中心にやってい らっしゃって，いかがでしょうか。

後山 漢方の使用量とか使用頻度というものを 全国的に調べると，一番漢方を使用するのはどう も産婦人科のドクターという結果が出ました。そ れはなぜかということを考えますと，やはり産婦 人科の機能疾患そのものが非常に多いということ, すなわち内分泌的な問題が非常に大きいというこ とがあります。そういう中で, 我々が日常的に産 婦人科診療をやっておりますと，どうしても漢方 が必要な場面に，毎日のように遭遇します。真剣 に産婦人科の医療をやっておりますと漢方の必要 性が自然に生じてくるということです。私たちは 西洋薬と漢方薬を使う際に, 西洋薬をまず使って, それで残った部分に漢方薬を使うのが一般的では ないかと考えますが, 最初から漢方薬の使用の方 が考えやすいような病態を持っている患者さんが 産婦人科領域の機能性疾患では非常に多くおられ ます。

おそらく女性はもともと瘀血がベースになって いるということもあるでしょうし，最近のストレ
ス社会で気虚のような問題も加わってきて, 病態 は非常に複雑になっています。しがたって, 西洋 医学的に一生懸命病態を考えるよりも気・血・水, あるいは五臓六腑という漢方理論で考えた方が病 態が把握しやすいのです。産婦人科という領域で は，漢方というものは本当に西洋薬とほとんど同 じょうな，天秤にかけてほとんど同じ，どちらが 重いとは言えないというポジションにあると思っ ています。

大澤 ありがとうございました。次に漢方では 漢方薬が大切ですが, 西洋医学の面からは本当に 効くのかという疑問が出ることがあります。この 点で大切なのは，漢方の専門家が，漢方薬は本当 に効くという感触を明らかに示していただくこと たと思うのです。

そういう意味で，寺澤先生から私の方に欲しい 情報は，漢方薬が本当に位置づけのある，ちゃん とした薬であるとしてょろしいでしょうか。漢方 の専門家にそれを言っていただくことが，一番の 我々の支えなわけです。いかがでしょう。

寺澤 そうですね，もうこの 21 世紀に無くては ならに医療の大系です。つまり植物資源でありま すから，大事に栽培したり，自然とのつき合い方 さえ節度をもって行えば，いつも再生産可能な資 源なのです。まずエネルギー的にいって非常に自 然なわけです。そういうもので，この地球環境上 に生きる我々人間のこの健康を維持したり，ある いは疾病状態を健全に戻すという方法論は，むし ろ主流になっていかなければならないのではない か。もうそういうふうな確信に満ちています。も う漢方を知らない医者は医者でなくなるという時 代が近々来るのではないかと思っております。

大澤 そこまで言っていたたくと非常に結構な のですが。私が申し上げたかったことは，漢方薬， あるいは漢方薬を使った漢方医療が本当に説得力 があり，確実に臨床上役に立つということを納得 するのは，本当の専門家がこれが効くという感触 をもつことなんですね。もう理論でも何でもない のです。さっき寺澤先生がおっしゃいました五感 じゃないですが，「勘」みたいなものです。それ が実はほとんどの西洋の新薬のすべてについて言 
えることだと思います。そういう意味で, 寺澤先 生の力添えをいただいてうれしく思いました。

あとは扔一言ずつお願いします。私自身申し上 げましたが，漢方がどうして定着しがたいかとい うと, 西洋医学の基盤（医療行政から何からそう いうことなのですが）からすると，個ではなくて マスの評価であるわけです。それは先程寺澤先生 の「養生」という言葉にも出てきましたけれども, 漢方は個々の患者の治療，医療であって病気の治 療ではないということからみて, 漢方, 漢方薬を 定着させるうえでの患者中心の見方というものは どういう評価になるでしょうか。裏辻先生からお 願いします。

裏辻 患者さんは「ここへ来ると脈をとってく れる」とおっしゃいます。「じゃ，よその先生で は脈を診ないのですか」と尋ねますと「脈をとっ てもせいぜい片方で，ちゃんと拍っとる」とか， 血压にしましても私のところでは両側で測定しま すが，片側だけで測定される先生もかなり多いよ うです。漢方を実践するものには考えにくいこと ですが，私も漢方を始めるまではそうでした。そ ういう意味で漢方診療は患者さんに喜ばれます。 食養や機能性食品についても，かなり梁く尋称ら れます。専門外の患者さんでも，先ずクリニック を受診されます。

患者さんは常に最高の医療を求めています。医 療サイドからみると, 現代医学であれ, 漢方医学 であれ，患者さんが納得のいく満足できる医療を 提供すべく努力されている先生方の姿勢にあるの ではないかと思います。

大澤 なるほど，アメリカの医療で，ほぼ20年 ほど前から決まってきたことは，医療の決定権は 医者にはなくて患者にあるということが根付きつ つあるわけですが，そうしましたときに，患者が 本当にそれを信頼して診療を受けるときの対象が 漢方であったということになるかと思うのです。 後山先生, 先生の立場からいかがでしょうか。

後山 今の若い, 大学病院のドクターが日常の 診療に漢方を使わない理由の一つに，「別に漢方 薬を使わなくても診療ができるから」という意見 があります。ただ,やっぱりそれは大きくまちがっ
ているのではないかと思うのです。これは寺澤先 生も拈そらく感じておられると思いますけど，全 人的医療, すなわち患者中心の, 本当に臓器別で はなくて患者全部をトータルのものとして診る見 方をすると，漢方薬を使わざるをえない状況に必 ずなるのです。漢方医学というのは，先程，寺澤 先生に修正されましたが，いわゆる自然科学を包 含する非常に大きな医療体系であります。今，心 身医学というものが非常に脚光を浴びていると同 じように，漢方医学も心身医学と同じような考え 方で患者さんをトータルでとらえて診るというこ とを一番のベースとしています。そういう教育を 本当は卒前教育として大学でやっていかなくては ならないと思っています。私もそれをかなり実践 しているのですけれども, 卒業した若い先生が, せめて漢方薬を基本的に使えるような知識を医学 教育の中で実践していき，そのことが，最終的に は患者さんのトータルケアに恩恵を与えるのでは ないかなと思っております。

大澤 寺澤先生，一言でまとめてください。

寺澤 結局, エデュケーション (教育) だと思 います。とてもうれしい話は, 福井医科大学（隣 なのですが) は和漢診療学といいますか, 東洋医 学の必修のプログラムを立ち上げました。こちら から講師陣を送っています。今年から岡山大学と 名古屋大学でも110分のコマが8コマぐらい, 大 体の初歩的なところを教えることができるのです が，こういうのが国立大学を中心に広がっている。 私は本当は私立大学でこそ広がるべきだと思うの です。つまり，いわゆる国立大学は研究者志向み たいなところがあるのですからね。ですけど，そ ういうことで医育機関で，今，漢方が相当見直さ れだしたという大変明るいニュースがあります。

大澤 将来の一番大事なことは, 若い人の教育 だということに尽きると思います。それでは，ど うも 3 人の先生方，ありがとうございました。今 後のご発展をお祈りしています。そして，最後ま でご清聴いただきましてありがとうございました。 
第51回日本東洋医学会学術総会

\section{学会シンポジウム}

\section{1世紀における銊尒治療の役割}

座長：伊藤 嘉紀

1. 総合医療施設に打ける銊尒

石野 尚吾

2. 21世紀に於ける鍼多療法の役割

——与えられている課題と私共の取り組み——

光藤 英彦

Roles of Acupuncture and Moxibustion Therapy in 21 st Century

Chairperson : Yoshiki ITO

Presentator : Shogo ISHINO, and Hidehiko MITSUFUJI

Nihon Toyo Igaku Zasshi (Japanese Journal of Oriental Medicine), 51(5), 941-970, 2001

(Accepted ; 24 Jun., 2000)

伊藤 シンポジウム 4 「21世紀に扔ける銊炎治 療の役割」を始めたいと思います。時間がもった いないので先に始めましたが，まずはこのような タイトルでシンポジウムが持てる幸せを，会場の 皆様とともに感謝したいと思います。また，この ような企をしていただきました大会会頭の細野 八郎先生はじめ，関係者の皆様に㧍礼を言いたい と思います。

「21世紀の銊尒」と大きいタイトルではありま すが，1900年（今から100年前）にどういうこと が起こったかというと，1つは浅井国幹先生が漢 方復興運動に敗れ, 名古屋へ帰って祖先の墓の前 で「告墓文」を奉読された年でもあります。この とき大塚敬節先生が抄生まれになっています。簡 単に考えると，100年経つと世の中は逆になって
いるのではないかという可能性があるのではない かと思います。そういう意味で, 鍼炎の置か机て いる立場も，ひょっとすると100年後には逆転し ているのではないか。アメリカではそういう兆し が芽生えたりしていますし，近いところでは石油 が30年後にはなくなる，あるいは，化石燃料使用 のために炭酸ガス濃度が増えているということで, あながち夢でもない。可能性もあると思います。

100年後を見通すことはなかなか難しいかもし れませんが，基本はやはり，患者さんを東洋医学 的に，西洋医学的に診断して，上りよい治療をす ることだと思います。そのとき，100年後に東洋 医学としてのシステムがそのまま残り，西洋医学 のシステムがそのまま残っているのか，あるいは それをインテグレートしたような新しい医学体系

第51回日本東洋医学会総会（2000年 6 月24日，京都）ょり 
ができて，それに従って診療が行われるのか，そ の辺が一つの見所ではないかと思います。

本日の演者のおふたかたは，私も同年代なので すが，「鍼尒や漢方を口に出すと出世の妨げにな るから，あまり言わない方がいい」という時代で した。その中にあってこのように銊尒を専攻され， 時代の最先端を行く総合病院で鍼尒治療を実践さ れてこられた先生ですので，非常に参考になる話 が伺えるのではないかと思います。

それでは，まず石野先生からお話を伺いたいと 思いますが，恒例に従ってご紹介させていただき ます。昭和 41 年, 昭和大学医学部をご卒業され, 42 年に日本医科大学産婦人科教室に入局, 医局長を 歴任されました。51年に医学博士となられ，59年， 日本医科大学産婦人科講師を兼任されました。昭 和59年, 北里研究所東洋医学総合研究所客員部長, 同61年, 北里研究所東洋医学総合研究所診療部長。 学生のころから故丸山昌朗先生に鍼尒, 漢方を直 接師事されました。日本医科大学産婦人科教室在 学中より銊尒・漢方治療を行い, 針麻酔により手 術，分婏をされました。お父様が石野信安先生と いう非常に高名な漢方・銊尒を使われる先生でし た。現在は, 北里研究所東洋医学総合研究所診療 部門長, 日本東洋医学会常務理事, 日本医科大学 産婦人科講師 (兼任), 学校法人東洋鍼尒専門学 校校長, 財団法人日本漢方医学研究所常務理事で す。それでは先生，よろしくお願いいたします。

\section{1. 総合医療施設における鍼炎}

\section{石野 尚吾}

東京・北里研究所東洋医学総合研究所

石野ただいまご紹介いただきました石野です。 座長の労をお取りいただきます伊藤先生，どうも ありがとうございます。過分なご紹介，恐縮に存 じます。またこの機会をお与えくださいました 細野会頭に心から扮礼申し上げます。それでは， ただいまより始めさせていただきます。

\section{1. はじめに}

「21世紀に扔ける銊尒治療の役割」という，非 常に大きなテーマを頂きました。その中で，私は 総合医療施設に於ける銊尒の立場から括話させて いただきます。

北里研究所東洋医学総合研究所 (以下東医研) は，診療部門と研究部門からなっています。診療 部門は銊尒診療部，漢方診療部，薬剂部で，研究 部門は基礎研究部門, 臨床研究部門, 医史学部門 があります。銊炎診療部，漢方診療部は互いに独 立して受診者は各自が選択してそれぞれの診療を 受診しています。そして同じ敷地内に隣接して北 里研究所病院があります。診療情報としてのカル テ等はそれぞれ独自のものを使用していますが必 要に応じて常に閲覧する事が叮能であり臨床検査 結果等は共有できます。

\section{2. 総合医療施設に於ける鍼炎診療}

将来を推測する方法として過去を知り現在を確 認してこの二つから将来を予測するのも一つの方 法であります。そこで東医研開設以来 25 年間, 特 に最近10年間を振り返り銊尒診療の独自性，西洋 医学との連携等を検討し，その中から将来を模索 し来るべき 21 世紀に於ける銊尒の診療形態，役割 等について述べてみます。

図 1 に示すように，鍼炎治療の独自性に関して は当科の特徵，患者動向，漢方診療との関連性， 


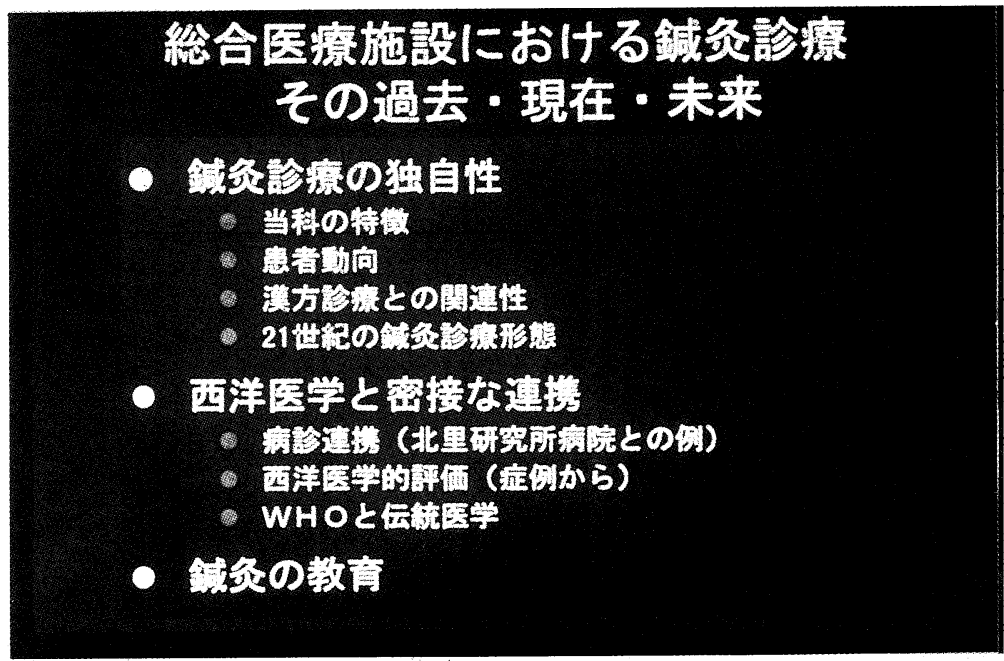

図 1

\section{北里研究所東洋医学德合研究所における 鍼炎訅療の特徽}

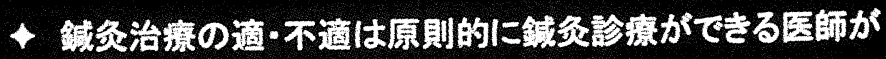
行了。

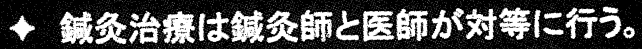

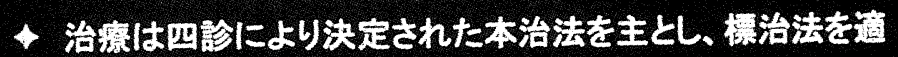
宜加える。

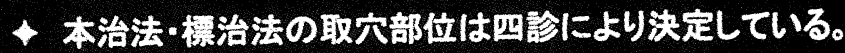

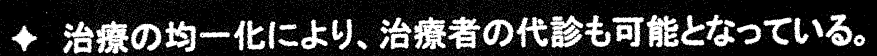

^オーダリングによるア約制を行っている。

図2

将来の銊尒診療形態について述べます。次に西洋 医学との密接な連携については特に北里研究所病 院との関連性を例として病診連携について述べま す。さらに西洋医学的見地から銊尒治療の具体的 な効果について述べます。WHO と伝統医学（鍼 炎医学）の関連性を述べます。次の教育について は時間の関係で触れることは難しいでしょう。

（1）鍼炎治療の特徴

当部では（図２）銊炎治療の適応について銊炎 治療のできる医師が判断を行い，治療は銊尒師と
医師とで平等に行っています。

治療は四診により本治としては世間でいう経絡 治療を行い必要に応じて, 対症療法を加えていま す。取穴については古今の多数の文献と我々の経 験を加えてッボを統一してあります。受け持ち制 で診療を行いますが治療方法の統一化, 均一化に より担当者の代診もスムーズに行われています。

過去10年間の患者さんの動向について, 東医研 は東京のほぼ中央の港区にあります。交通の便は バスと地下鉄利用で，JR 駅近くと比べれば少し 


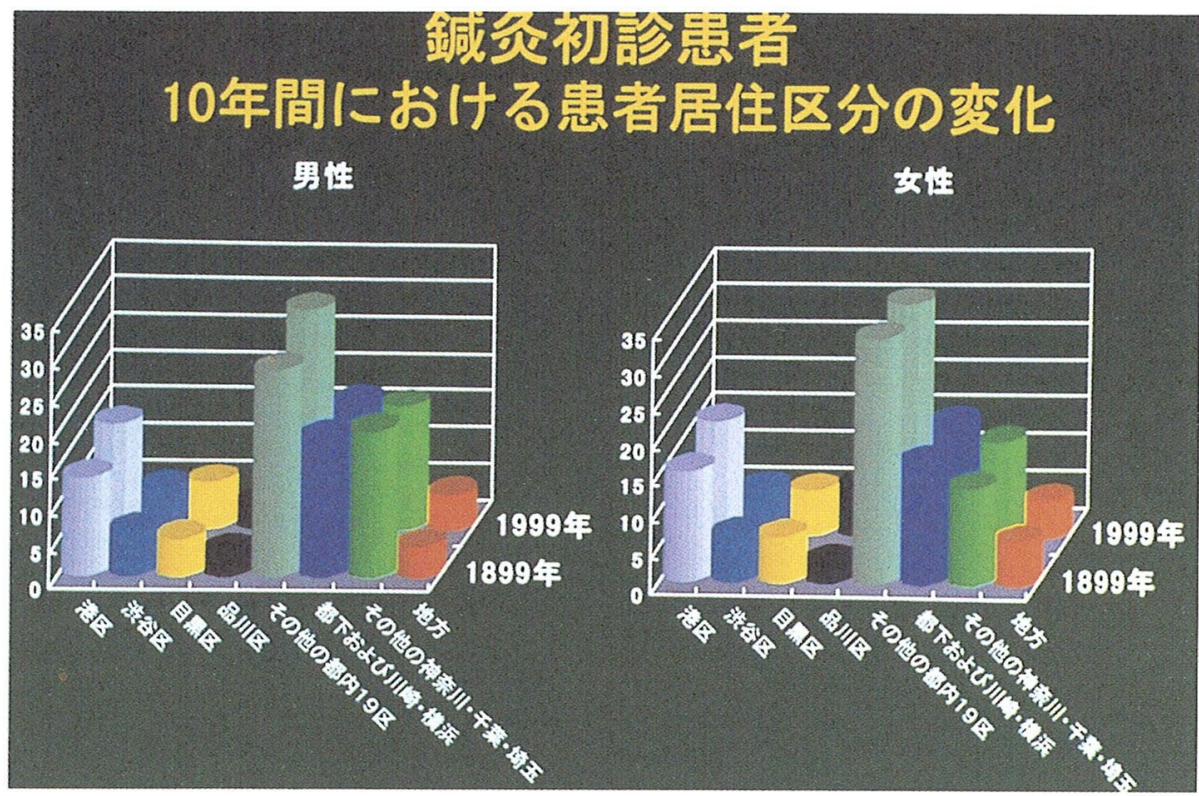

図 3

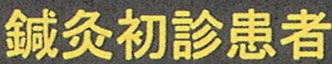

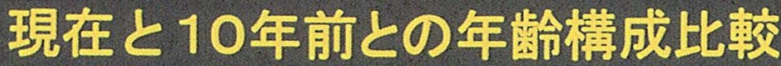

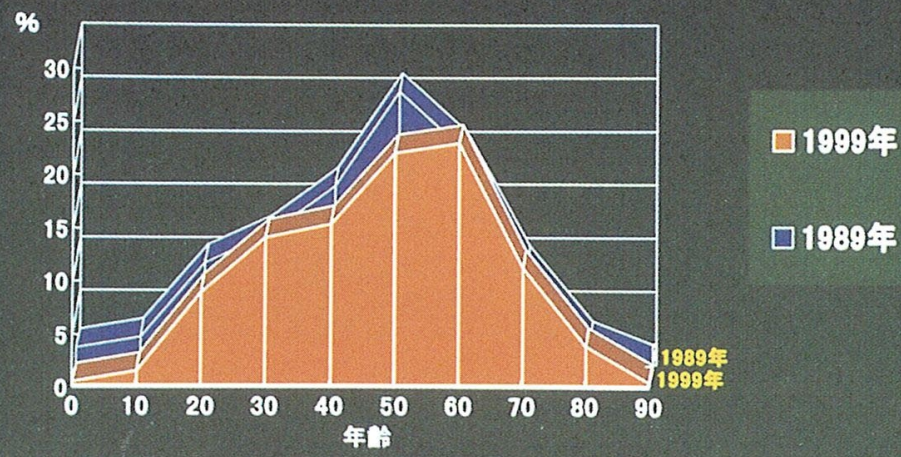

図 4

アクセスは良くありませんが比較的めぐまれた環 境にあります。来院される方々の住居区在示しま す（図３）。港区内，隣接区である品川，目黑， 渋谷区さらに23区内, 都下, 川崎, 千葉, その他 地方加と広範四から来て頂いています。その割 合は10年前とほぼ同じです。

初診時年齢構成です (図 4)，1989年の初診時
の年龄がピークは50歳でしたが，10年後1999年の 初䜌時年齢のピークは60歳です。両年とも50歳〜 60歳で約 $50 \%$ 古占めていますがピーク年齢は10年 間に10歳高歯令になり，40歳が減少しています。次 に疾患・症状別動向ですがこの10年間で整形外科 系疾患症状，神経内科系疾患症状が70\% 75\% 孝 占めて大きな変化はありません。あとは神経科, 


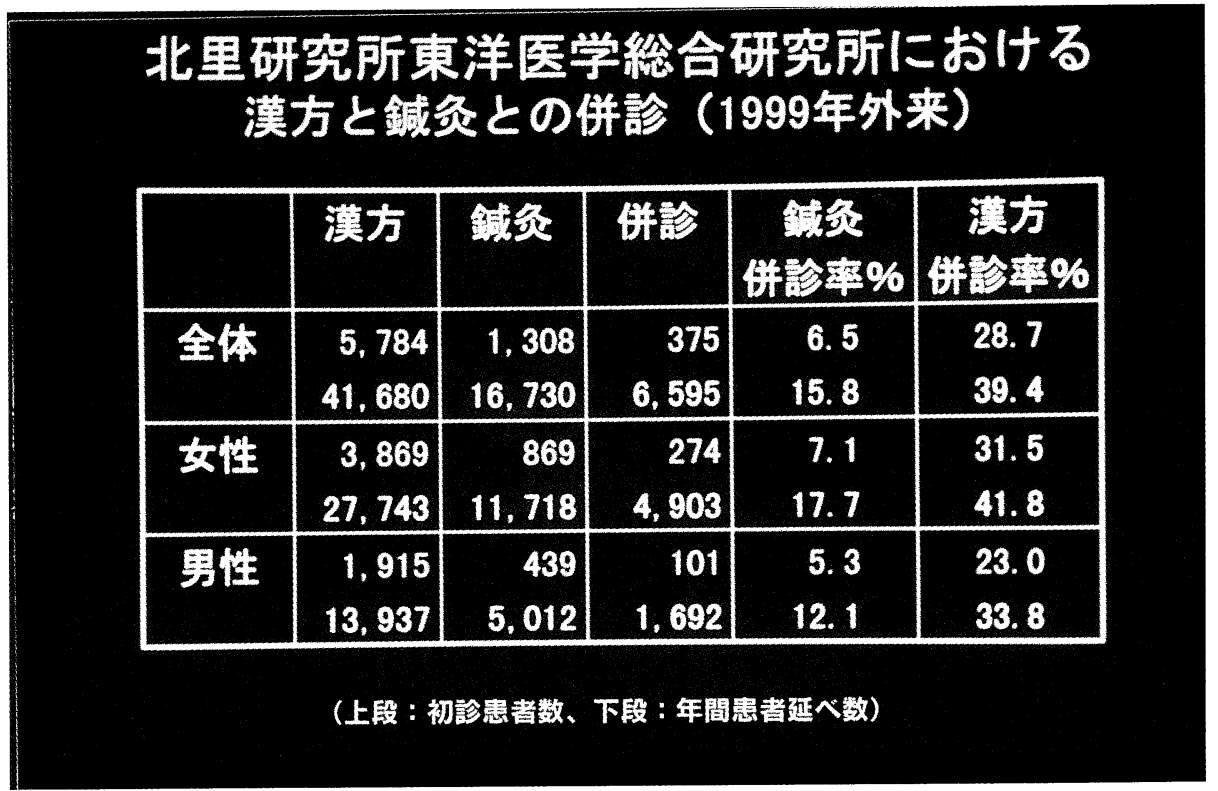

図 5

婦人科，皮膚科系疾患症状その他ですが，これも 10年間で両者の間に差はありませんでした。

整形外科系疾患症状，神経内科系疾患症状では 運動器疾患主に腰痛, 変形性膝関節症などで内容 は同じようです。内科系疾患・症状では気管支喘 息が10年前には多かったようですが現在は減少し ています。その他高血圧症，慢性胃腸炎，慢性便 秘，過敏性腸症候群などでありますが，「その他」 が多くなっています。

婦人科系疾患症状では98年には月経困難症が 25\%をしめ多かったようですが，最近は7\%に なっています。冷え症の患者さんが98年の30\%か ら99年は50\%と増加傾向にあります。他は更年期 障害等ほとんど変わらないようです。月経困難症 の減少はこの10年間に於ける西洋医学の発展によ るものと考えられます。

(2) 鍼尒・漢方併診について

我々のところには漢方と銊尒の診療部がありま すが，それぞれ独立しています。患者さんの希望 により，漢方を受診するか鍼尒を受診するかを決 められるのですが，併診率を検討してみました。

これは1999年の患者状況です (図 5 )。年間初 診患者さんの中で，鍼尒を受診に来て漢方を併診
したいというご希望のあった方が $6.5 \%$ ，漢方に 来て銊尒を併診したいという方が $28.7 \%$ です。年 間ずっと来てくださっている患者さんについては, 鍼炎にずっと通っていて漢方を受診したいという 患者さんが15.8（約16）％，漢方にかかっていて 銊尒を受けたいという方が大体39.4（約40）％と 多く,これには私もびっくりしました。

内容を詳しく検討してませんが大半が, 同一症 状，同一疾患ではありません。漢方に来ている方 が，肩がこったり，腰痛があって自宅近くで鍼尒 治療を受けていて，ここにあると知らなかった， ぜひここで受診したいというような感じでそれ以 来続いて来ていたたくということもあります。

「これは銊尒または漢方を併診した方が効果があ る」「これは銊炎の方がより適用ではないか」と いう医師の説明の中での総合した併診もあります。 男女比は大体似たようなパーセンテージです。初 診, 再診でも, 併診率が女性で少し多いのは, 診 療時間に関係があると思います。

まず東医研銊尒部を受診されます。鍼尒診療部 で治療をして，それでいい方はそれで纬りいた だく。漢方を受けたい方は漢方を併診し, 漢方に 来て鍼尒を受けたい方は鍼尒にきます。カルテは 


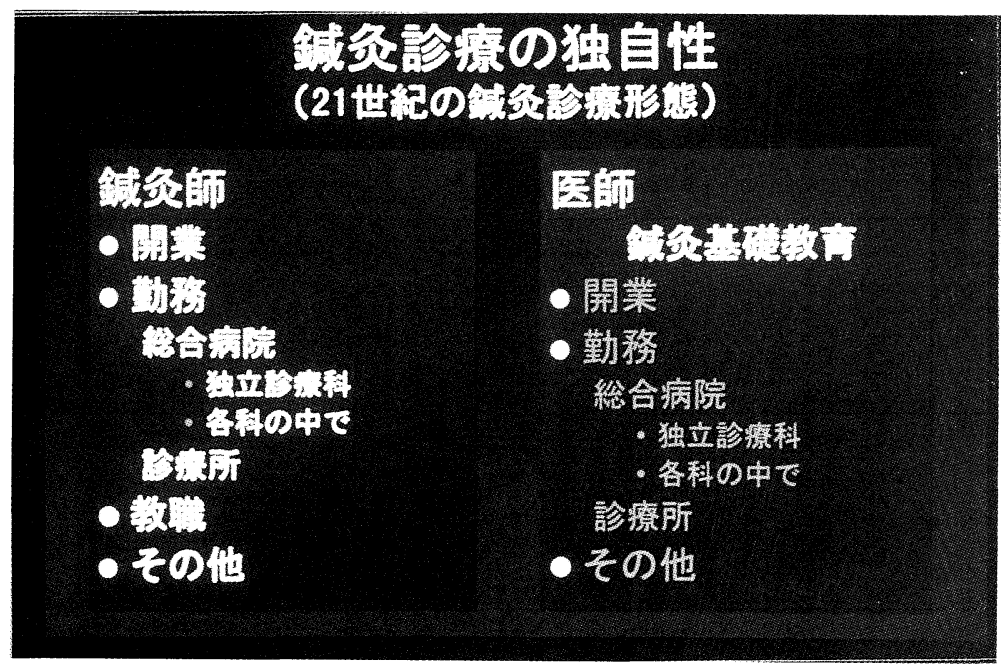

図 6

独立していますが 1 冊に併合されているので常に 閲覧でき検查等は步有です。

（3） 21世紀における銊尒診療形態（図 6 )

銊炎診療の独自性について，21世紀の銊尒の形 態を考えてみました。あと 3 年経つと，規制緩和 により鍼尒専門学校, 短期大学, 大学の年間卒業 生は約5000人になると思われます。10年で 5 万人, 過剰時代になるのかもしれません。その中で，鍼 尒師は開業を選ぶ，これは在宅医療にかかわって 往診というかたちをとることも増えてくるでしょ う。勤務というかたちでも, 総合病院の中で鍼尒 科として独立して科を設立する可能性，また，各 科の中で銊炎治療を行うなど考えられます。診療 所の開設もあるでしょう。それから，教職という 選択肢も出てくると思います。これだけ一気に増 える中では，鍼尒を専門に教えられる，質のいい 先生は非常に少なくなってくるということもちら ほら聞いています。医師については，銊尒を専門 にやりたいという人については鍼炎の基礎教育が 必要です。これはかなりしっかりした教育をしな いといけないと思います。その教育スタッフも必 要ですし, 設備も必要かと思います。そして選択 は, 開業, 勤務, 等々, 鍼尒師の場合と同じよう になると思います。

(4) 東医研と北里研究所病院

これは北里研究所の組織の説明です。東洋医学
総合研究所と北里研究所病院とは独立した組織で す。

組織図とすればこのようになります（図７）。 病院, 研究所, それぞれ独立しています。

診療連携ですが，我々のところは自由診療です。 北里研究所病院は保険診療ですので, 自由診療と 保険診療の中でいかにうまく連携していくかとい うことですが，院外紹介状でお互いに受診でき， 情報の交換もスムーズにできます。我々が，どう しても検査をしたい，レントゲンを撮りたい，血 液検査をしたいときには，病院を受診してもらい に検査依頼になります。院外紹介状を書いて診察 を依頼しています。病院のオーダリングシステム と我々のオーダリングシステムは連結されており， 検査結果はコンピュータで同時に閲覧できるシス テムになっています。また, 受診直後から西洋医 学の精査, 併診が必要と考える場合には, それぞ れの科に紹介します。もち万んその結果も, 検査 結果と同様にオーダリングシステムをもって我々 は閲覧できるシステムになっています（図８）。

また, 病院からも外来の患者さん, 入院の患者 さんの紹介をいただきます。さらに，新橋にある 附属の北里研究所クリニックからも外来の患者さ んが来られます。

去年 1 年間, 研究所病院に入院中の患者さんで 鍼尒部へ紹介を受けた症例は24例です。いろいろ 


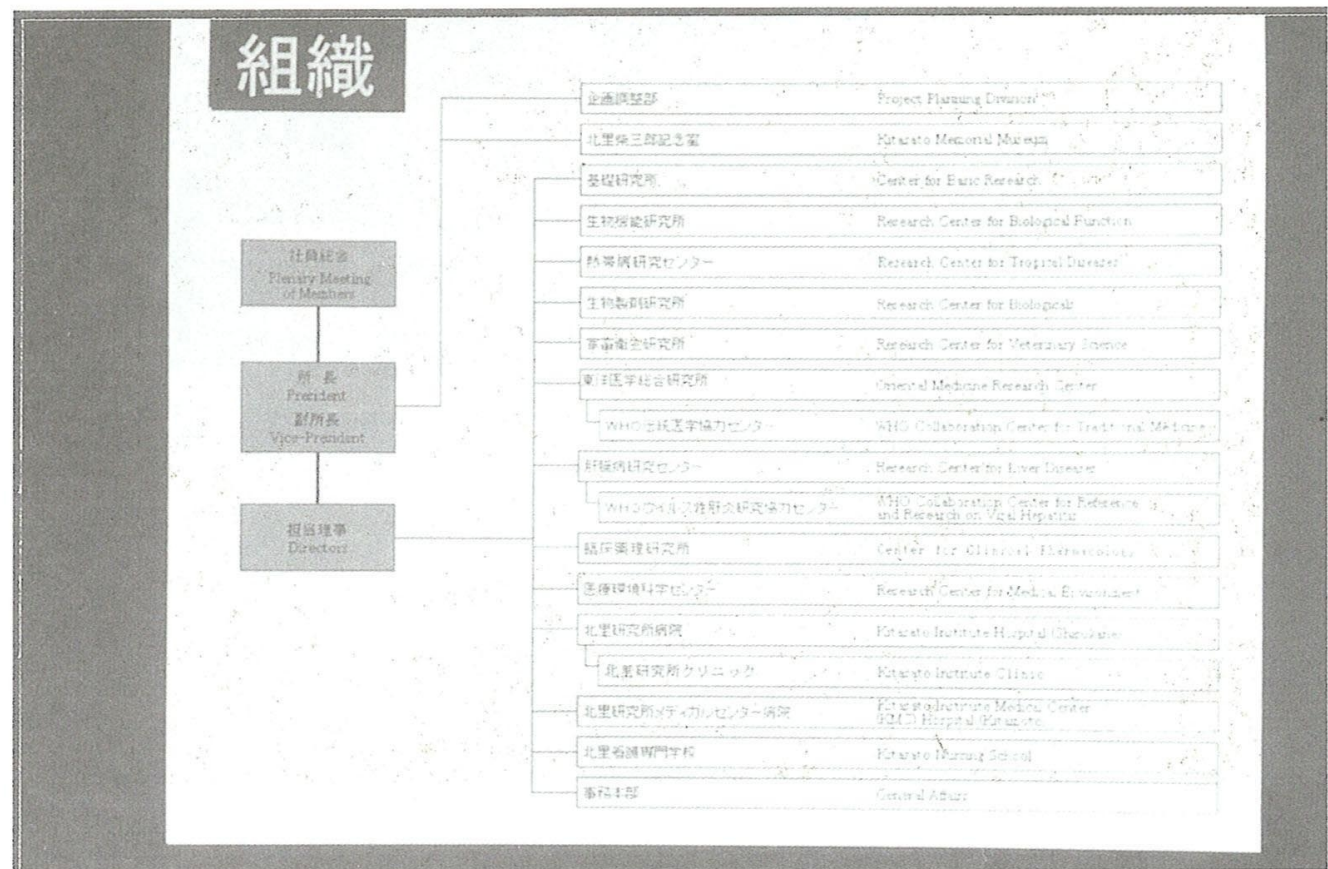

図 7

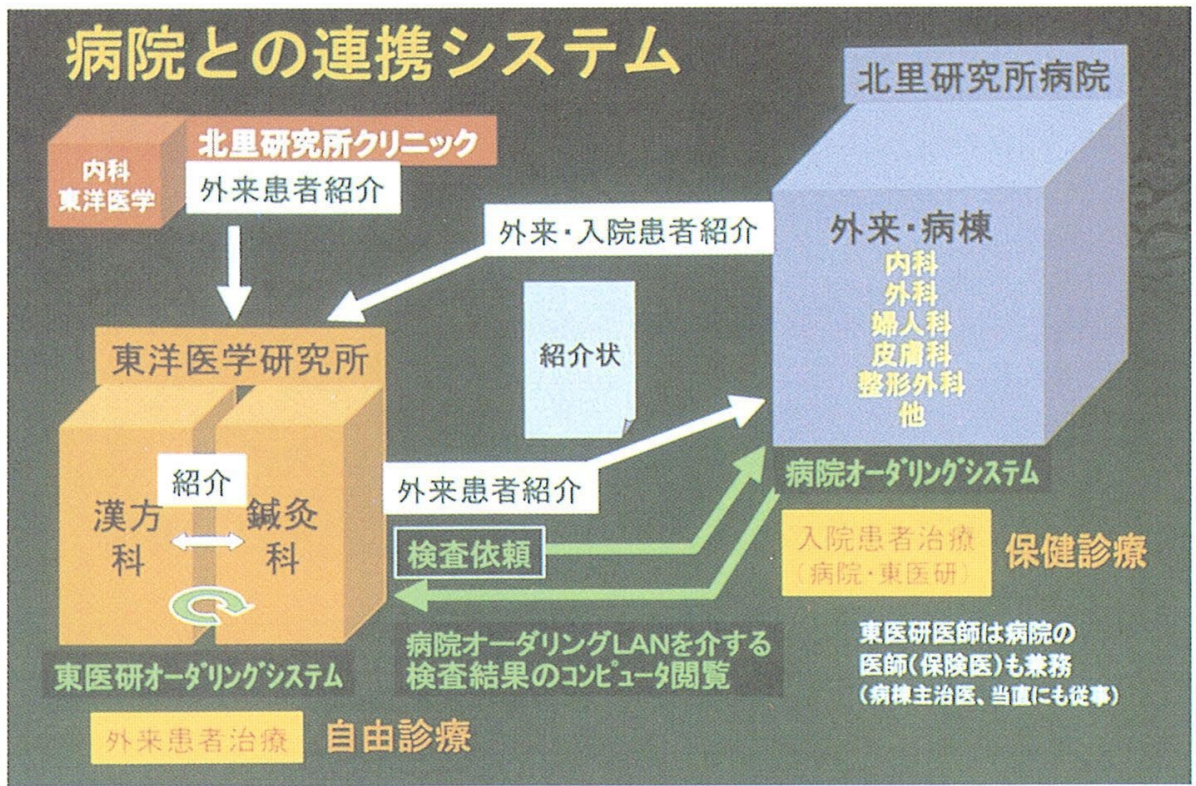

図 8

な疾患があります（図 9)。症状については，肩 こり, 痛み, 腰痛等が1つではなく重複した症状 で依頼孝受けます。依頼を受ける場合に，外出で
きる，動ける患者さんには我々の施設に来ていた だく。動けない万はこちらから往診診療に行くと いうことになりますが，全員，東医师の受診カー 


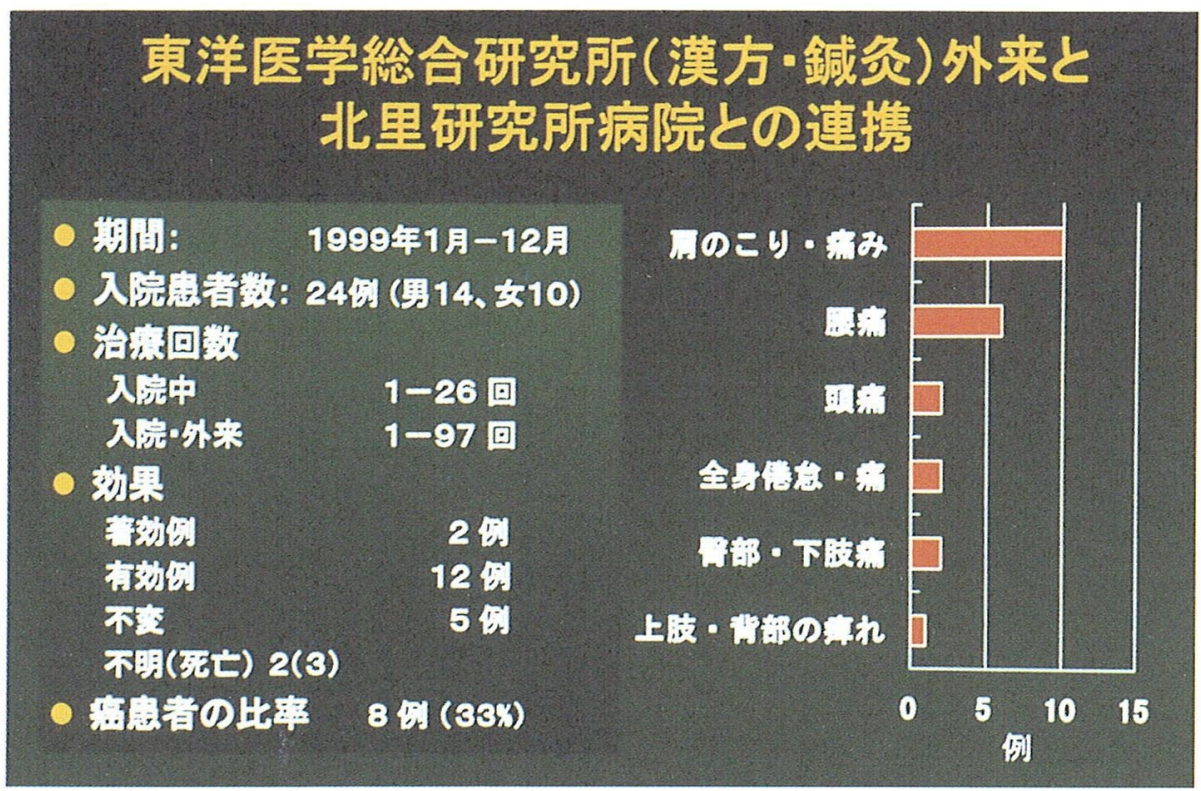

図 9

現代医学的評価法を用いて分析した臹色治療の邅店

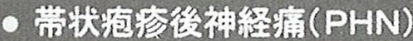

Visual Analog Pain Soale (VAS)

PHN貫者29;寉例中

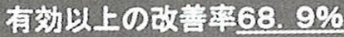

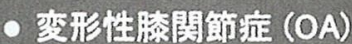

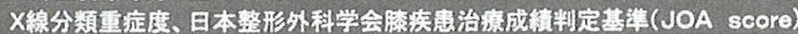

Visual Analog Pain Soale (VAS)

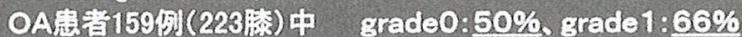
grade2:5.8\%, srade8: $50 \%$

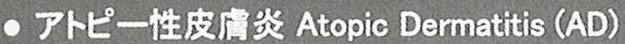

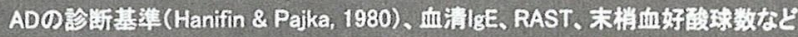

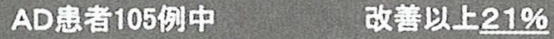

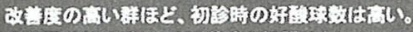

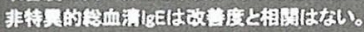

図10

ドを作っていただいて，カルテを作り，病院のカ ルテには一切記入はせず，我々の方で診療日誌は 保管しています。もちろん，逐次主治医には治療 内容・結果についてご報告させていただいていま す。

(5) 銊炎治療の効果判定

この学会で発表させていただいたものです（図 10)。このように带状庖疹神経痛（PHA）に関し
てはVisual Analog Pain Scale・(VAS)により, 判定をしています。また，変形性滕関節症 $(\mathrm{OA})$ に関しては屈性分頪重症度, 日本整形外科学会滕 疾患治療成績判定基準 VAS 等によりこのような 結果を報告しています。アトピー性皮膚炎に関し ても，IgE，好酸球等々をチェックしています。 改善度の高いものほど初諩時の好酸球率が高かっ た，重症度とは関係ない等も発表させていたたい 


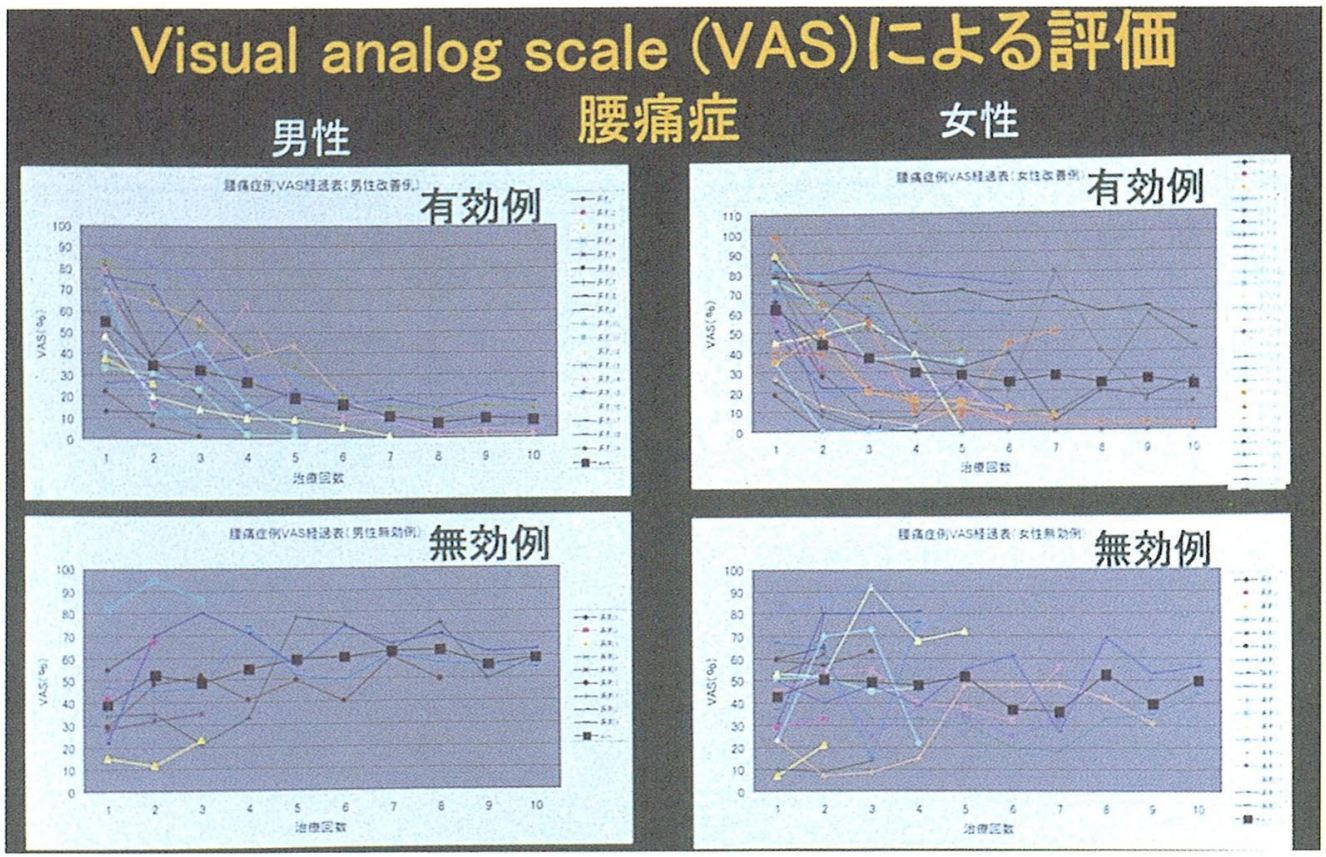

図11

\section{STANDARD ACUPUNCTURE NOMENCLATURE PART 2 REVISED EDITION}

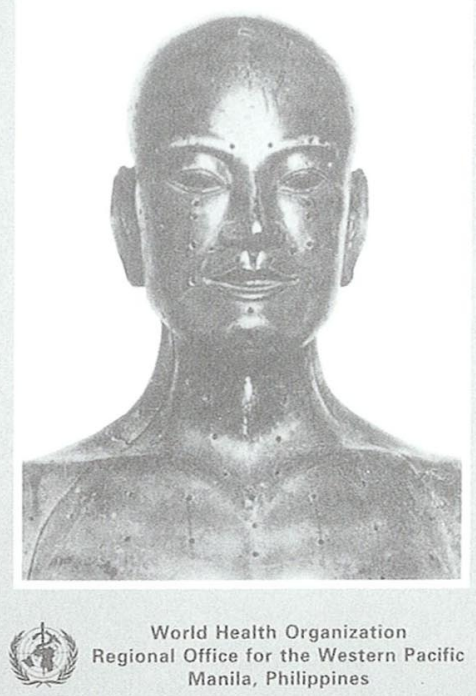

図12-1
ています。

これは腰痛症のVASによる評洒を示すもので す（図11）。腰痛という症状に刘して有效なもの と無効なものがある。これを銊尒治療が，どのよ うな原因・種類の腰痛に有效であったかというこ とを検討していって，今後の診療に役立て，EBM の確立を目ざしています。銊尒の効果のあるもの, 効果の弱いもの等々，きちんと区分けできればと 考えて作業中です。

(6) 東西医学の調和

WHO では，10年近く前ですが，フィリピンの マニラで会議をしたときにこのような小刪子を出 しています (図12)。

このように，世界共通のツボ，経絡について統 一をし，各国で対話ができるようなシステムを 作っています。

銊の効果があると思われる疾患を，WHO では 約50疾患, 症状を挙げています。緘の適用と言っ ていますが, ウイルス性の感染症, 痛み, 風邪, 中には急性細菌性赤痢などもWHOの適用には 入っているようです。このように，WHOは樍極 的に銊治療に取り組んでいます。 


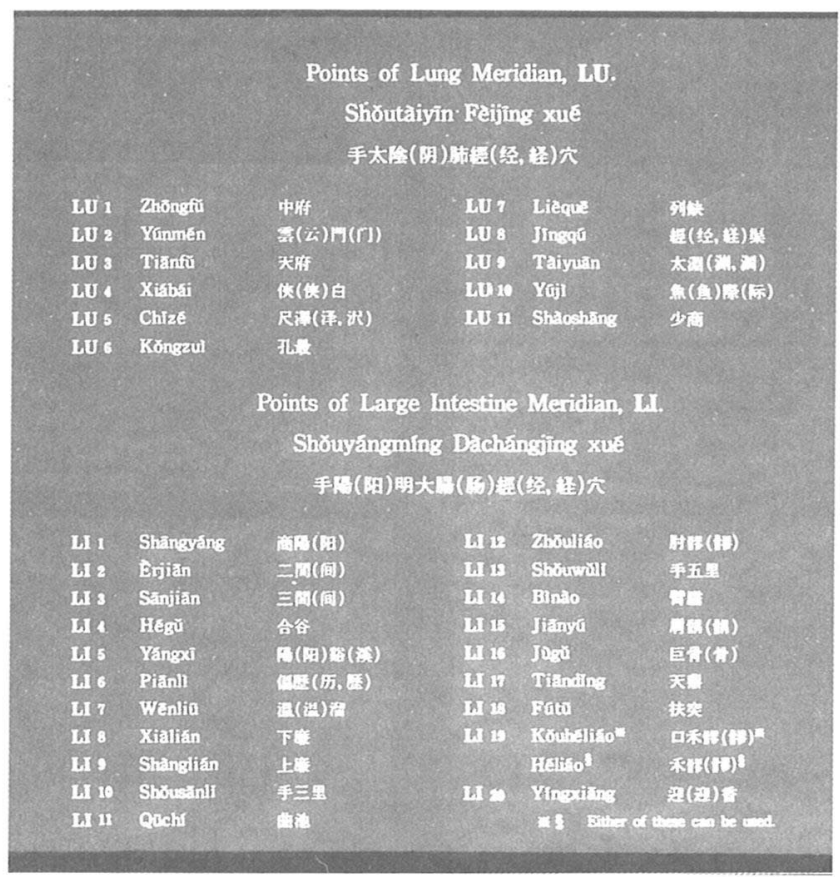

図12-2

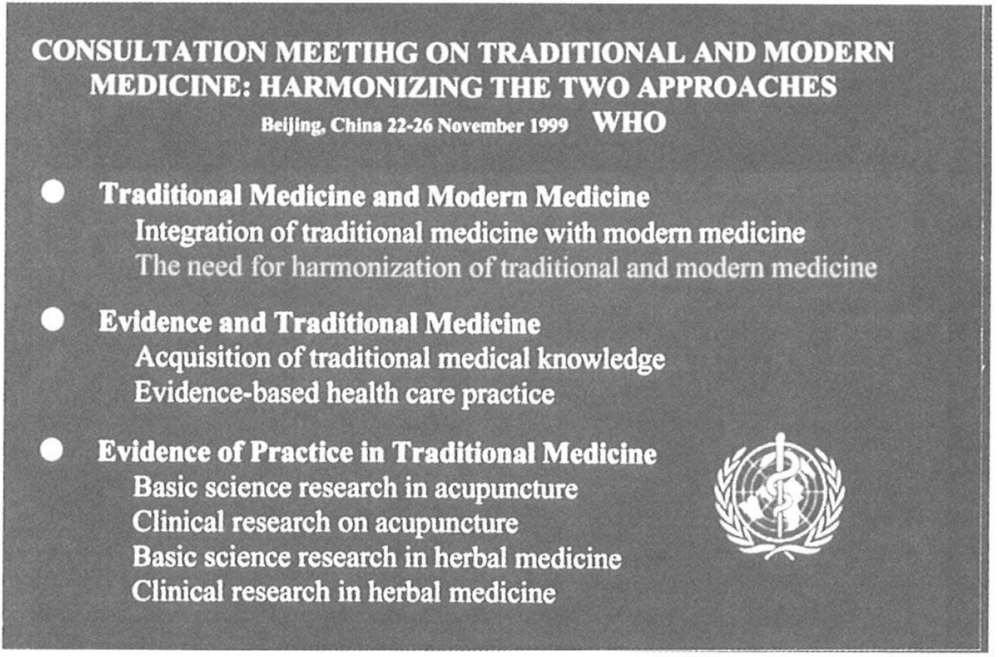

図13

1999年WHO の北京宣言です（図13）。これは， 伝統医学々現代医学・雨者の調和（ハーモナイ ゼーション)。EBMに基づいた統合による調和で す。統合ということで，唯今言わ玌ている代替で はありません。鍼尒は代替ではない。ここで私が 声を大きくして主涱したいのは, 銊尒の独立性,
独自性です。西洋医学の基準の下で銊尒治療をや るのではない。鍼炎治療は銊炎治療独自の理論に よって行う。その評偳については, 西洋医学的な 物童しをも加えていく。したがって，外来などで も独立した科として認めさせるような銊炎治療体 制を作っていきたいと念願しています。このよう 


\section{まとめ}

† 銊灭治亦は現代医学と統合し、互いに補完する ものである。

†銊炎治療は21世紀の高齢社会における医痖の 一翼をになうものである。

↔ 北里研究所東洋医学総合研究所のシステムは 病診連㷪のモデルケースと考える。

† 鉍色治療は我が国の医療の発展進歩と国民の 健康・福祉に有用である。

図14

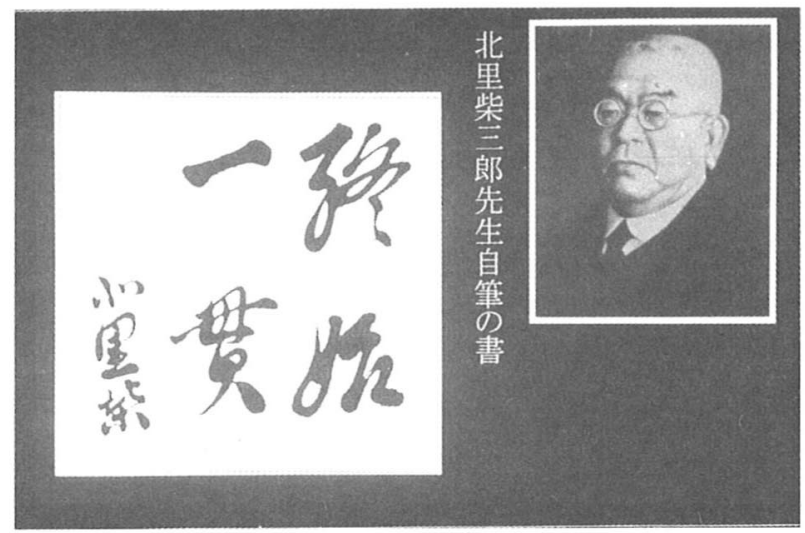

図15

に，現代医学と伝統医学，EBMに基づいた統合 による雨者の調和が，北京でのまとめだったよう に思います。

\section{3. まとめ}

これはまとめです（図14）。鍼多治療は現代医 学と統合し，互いに補完するものである。21世紀 は高齢社会です。これは高齢化ではありません。 高齢化は人口の $7 \%$ 以上が 65 歳以上であり, それ は我が国では1970年に突破しています。高齢社会 は65歳以上が人口の14\%以上で，1994年に笑破し ています。超高齢社会は同じく $20 \%$ 以上で, 2025 年になると $25.8 \%$ で以後獚這いということです。
北里研究所東洋医学総合研究所のシステムは, 病 診連携のモデルケースになるかと考えています。 銊众治療は我が国の医療の発展・進歩と, 国民の 健康福祉に有用であると確信いたします。

\section{4. 終始一貫}

北里研究所創設者の北里柴三郎先生直筆の「終 始一貫」です (図15)。非常にお好きな言葉と闒 いていますが, これは北里柴三郎先生が, 今まで 大勢の方々にお世話になってきた，そのおかげで 終始一貫細菌学に専念できた，ということです。 我々も，そういう気持ちを达めて，これから銊多 治療に, 東洋医学に専念してきたいという強い決 


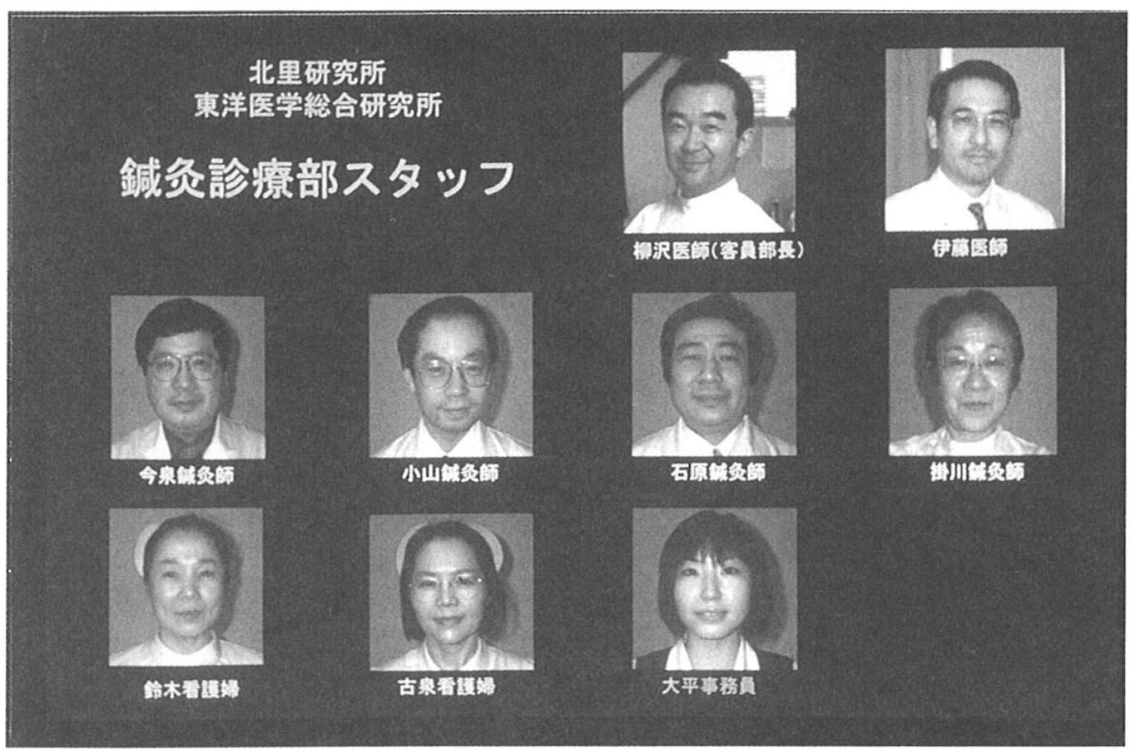

図16

意でここに出させていただきました。

\section{5. スタッフ紹介}

これが現在の我々スタッフです（図16）。今日， この発表をさせていただく機会をいただき，そし てこういう発表ができたのも，このスタッフの協 力があったものと思って感謝しています。

伊藤 続いて，「21世紀における銊尒療法の役 割一与えられている課題と私共の取り組み一」と 題して，光藤先生に扮願いいたします。

光藤先生の経歴をご紹介します。昭和40年, 東 京大学医学部医学科卒。昭和 41 年, 東京大学医学 部物療内科入局。昭和 49 年, 日産厚生会多摩川病 院東洋医学内科医長, 54年, 愛煖県立中央病院内 科医長兼東洋医学研究所長。昭和58年, 愛媛県立 中央病院内科部長兼東洋医学研究所長を歴任され ています。それでは光藤先生, よろしく扔願いし ます。 
2. 21 世紀における鍼炎療法の役割

一与えられている課題と私共の取り組み一

\section{光藤 英彦 愛媛県立中央病院東洋医学研究所}

光藤 ただいま伊藤先生からご紹介いただきま した，光藤です。伊藤先生には，本日の座長の労 をとっていただき，どうもありがとうございます。 とりあえずのレポートをまとめて抄録として抒
届けしてありますが，司会者の意図に従いお話の 内容を修正しましたので，本日扔話しする内容は 抄録とは異なる部分を追加してあります。ご了承 ください。

21世紀における銊尒治療の役割には，ご覧のよ うな 2 つ方向性があると思います（表 1 )。私 どもの施設でこの 20 年間一筋に取り組んできたこ

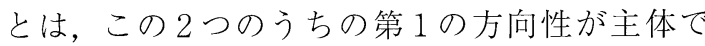
あったことを申し述べ，まずこの面についての紹 介をしたいと思います。

私ども，各自伝統医学への志は同じくするもの の，置かれた立場によって果たすべき役割に異な

\section{1. 鍼炎療法の二つの方向性}

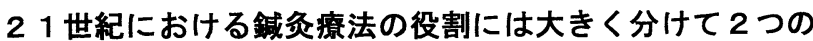
方向性があるように思われる。

第 1 は病人に対する役割であり、第 2 は全ての人類に対す る健康增進（ Health-Promotion）の役割である。（即ち保 健福祉目的である。）

第 1 の方向性には、アメリカで唱導されている" 代替医療” と云うレベルから、司会者の云われる"高次伝統医療"のレ ベルに至るまでの幅広い医療目的がある。

第 1 の医療目的の方から先に述へることとする。私は、た またま 20 年前の鍼麻酔報道の余波の中で、地域行政の要請 を受けて、地域中核医療の中での伝統医療の提供を実践する 使命を受けた。

表 2

\section{2. 愛媛東医研に課せられた役割}

私共の役割は

(1)私共の診療は”愛媛”の伝統生活文化としての炎療及 び刺絡吸角療法の肯定を前提とした発展的継承を行う 必要があった。

(2)高度な標準的サービスであると同時に一定量以上の量 的供給も必要とされた。(Publicityのため)

(3)少なくとも市中料金のレベルを超えるものであっては ならない。（月あたり又は年あたりの料金レベルを低 くする必要性あり。)

(4)他の専門医療に匹敵する技術集約型サービスでなけれ ばならない。

(5)時代の要請に応じて、病人中心医療と云う供給方法を 備える必要がある。 